\title{
UHMWPE-Layered Silicate Nanocomposites by in situ Polymerization with Tris(pyrazolyl)borate Titanium/Clay Catalyst
}

\author{
Fernando Junges, ${ }^{a}$ Mariana S. Beauvalet, ${ }^{a}$ Bárbara C. Leal, ${ }^{a}$ Adriana C. A. Casagrande, ${ }^{a}$ \\ Fábio F. Mota, ${ }^{b}$ Raquel S. Mauler ${ }^{a}$ and Osvaldo L. Casagrande Jr. ${ }^{a} *$ \\ anstituto de Química, Universidade Federal do Rio Grande do Sul, Av. Bento Gonçalves, 9500, \\ 90501-970 Porto Alegre-RS, Brazil \\ ${ }^{b}$ Centro de Inovação e Tecnologia Braskem, Via Oeste, Lote 5, Passo Raso, III Pólo Petroquímico, \\ 95853-000 Triunfo-RS, Brazil
}

\begin{abstract}
Nanocompósitos de polietileno-MMT foram preparados através da metodologia de polimerização in situ utilizando $\mathrm{Tp}^{\mathrm{Ms}}{ }^{*} \mathrm{TiCl}_{3}$ (1) intercalado na galeria da Cloisite ${ }^{\circledR} 30 \mathrm{~B}(\mathrm{C} 30 \mathrm{~B}) \mathrm{e}$ na presença de metilaluminoxano (MAO) como ativador. Através da análise de difração de raios-X (DRX) foi observado que o espaçamento basal da argila ativada muda de $1,85 \mathrm{~nm}(2 \theta=4,8)$ para $2,18 \mathrm{~nm}(2 \theta=4,0)$ indicando a ocorrência da intercalação do catalisador de titânio na galeria da argila. O sistema catalítico 1/C30B/MAO foi ativo na polimerização do etileno sob diferentes condições reacionais. A morfologia esfoliada do nanocompósito PE-MMT foi confirmada pela análise de difração de raios-X (DRX) e microscopia eletrônica de transmissão (MET). A presença de argila esfoliada ( $5 \%$ em peso) na matriz polimérica confere melhores propriedades mecânicas (módulo de flexão e módulo de armazenamento) quando comparada com aquelas apresentadas pelo polietileno puro produzido exclusivamente por $\mathbf{1}$.
\end{abstract}

Polyethylene-MMT nanocomposites were prepared by in situ polymerization methodology using $\mathrm{Tp}^{\mathrm{Ms}^{*}} \mathrm{TiCl}_{3}$ (1) intercalated into the gallery of Cloisite ${ }^{\circledR} 30 \mathrm{~B}(\mathrm{C} 30 \mathrm{~B})$ using methylaluminoxane (MAO) as activator. From the powder X-ray diffraction (XRD) analysis it was observed that the basal spacing of the activated organoclay changes from $1.85 \mathrm{~nm}(2 \theta=4.8)$ to $2.18 \mathrm{~nm}$ $(2 \theta=4.0)$ indicating that the intercalation of the titanium catalyst into the gallery took place. The catalytic system 1/C30B/MAO was active in the ethylene polymerization under different reaction conditions. The exfoliated morphology of the PE-MMT nanocomposite was further examined and confirmed by X-ray diffraction (XRD) and transmission electron microscopy (TEM) analysis. The presence of exfoliated clay (5 wt. \%) in the PE matrix confers better mechanical properties (flexural modulus and storage modulus) when compared with the ones displayed by the neat PE produced using exclusively $\mathbf{1}$.

Keywords: clay, UHMWPE, nanocomposites, titanium catalyst

\section{Introduction}

In recent years, polymer-clay nanocomposites have attracted much academic and industrial interest because of the anticipated improvements in mechanical properties, stiffness, thermal stability, chemical resistance, high barrier properties, flame retardancy, etc. when the aluminosilicate platelets of clays like montmorillonite are well exfoliated into polymers. ${ }^{1-4}$

Several methods have been adopted to prepare polymerclay nanocomposites, such as self-assembly of exfoliated

*e-mail: osvaldo.casagrande@ufrgs.br inorganic layers with polymers, template synthesis of layered crystals in the polymer solution, melting intercalation, and direct ion exchange of polyelectrolyte with hosts. ${ }^{5}$ More recently, special attention has been devoted to in situ intercalative polymerization methodology which is frequently also referred to as "polymerization filling". In this process, the monomer together with the polymerization initiator or catalyst is intercalated within the silicate layers and the polymerization is initiated either thermally or chemically. In contrast to highly viscous polymer melts, the polymerization reaction media have much smaller viscosity and enable easy dispersion of nanoparticles, provided that the compatibilities of media 
and nanoparticles are matched. Moreover, polymerization filling process can produce nanocomposites with much higher nanofiller content. This strategy has been utilized to produce a variety of economically important polymer-clay nanocomposites based on poly(methyl methacrylate), ${ }^{6-8}$ polylactide, ${ }^{9}$ polyurethanes,${ }^{10}$ poly( $\left(\varepsilon\right.$-caprolactone), ${ }^{11,12}$ and polystyrene. ${ }^{7,13-15}$ Furthermore, this approach has been extremely useful to produce well-exfoliated nanocomposites based on apolar polyolefins in spite of their hydrophobic properties that lack suitable interactions with the polar aluminosilicate surface of the clay. In this case, the vast majority of these studies are concerned to polypropylene, ${ }^{16-20}$ linear low-density polyethylene, ${ }^{21-23}$ and high-density polyethylene. ${ }^{24-32}$ On the other hand, just one example of ultra high molecular weight polyethylene (UHMWPE)-layered silicate is described in the literature using polymerization filling technique. For instance, Jérôme and co-workers ${ }^{33}$ reported the production of UHMWPE nanocomposites by in situ intercalative polymerization process using a titanium catalyst $\left[\mathrm{Me}_{2} \mathrm{Si}\left(\mathrm{Me}_{4} \mathrm{Cp}\right)\right.$ $\left.\left(\mathrm{N}^{\mathrm{t} B u}\right)\right] \mathrm{TiMe}_{2}$. Herein, we report the synthesis and characterization of intergallery-anchored $\mathrm{Tp}^{\mathrm{Ms} *} \mathrm{TiCl}_{3}$ $\left(\mathrm{Tp}^{\mathrm{Ms}^{*}}=\mathrm{HB}(3-\text { mesitylpyrazolyl })_{2}(5-\text { mesitylpyrazolyl })^{-}\right)$ into an organophilically modified montmorillonite clay (Cloisite ${ }^{\circledR}$ 30B), by methyl, tallow, bis-2-hydroxyethyl quaternary ammonium chloride $\left(\mathrm{MT}_{2} \mathrm{EtOH}\right)$, and its application in the production of UHMWPE-layered silicate nanocomposites.

\section{Experimental}

\section{Materials}

All manipulations were carried out under Ar atmosphere using standard Schlenk tube techniques. $\mathrm{Tp}^{\mathrm{Ms}^{*} \mathrm{TiCl}_{3}}$ was synthesized following procedures described in the literature. ${ }^{34}$ Cloisite ${ }^{\circledR}$ 30B (Southern Clay Products) was dried under vacuum $\left(\mathrm{P}<10^{-4} \mathrm{mbar}\right)$ for 8 hours at $150{ }^{\circ} \mathrm{C}$. Ethylene (polymer grade), provided by White Martins, and argon were deoxygenated and dried through column of BTS (BASF) and molecular sieve (3A) activated prior to use. MAO (Witco, 5.21 wt.\% toluene solution which contains $c a .20$ wt.\% TMA, trimethylaluminum) was used as received. Toluene and hexane were refluxed and distilled over sodium diphenylketyl complex prior to use.

Intercalation procedure of $\mathrm{Tp}^{M s^{*}} \mathrm{TiCl}_{3}$ into the activatedCloisite $^{\circledR} 30 B$

A toluene solution of $\mathrm{Tp}^{\mathrm{Ms} *} \mathrm{TiCl}_{3}(\mathbf{1})(0.021 \mathrm{~g}, 30 \mu \mathrm{mol})$ was canulla-transferred into predried Cloisite ${ }^{\circledR} 30 \mathrm{~B}(1.0 \mathrm{~g})$ toluene slurry $(20 \mathrm{~mL})$. The reaction mixture was stirred at ambient temperature for $24 \mathrm{~h}$. The slurry was then filtered through a fritted disk. The resulting solid was washed several times $(\mathrm{ca} .5 \times 10 \mathrm{~mL})$ with toluene at $50{ }^{\circ} \mathrm{C}$, and dried under vacuum for $24 \mathrm{~h}$. The resulting solid was named $1 / \mathrm{C} 30 \mathrm{~B}$.

\section{Polymerization procedures}

All polymerization reactions were performed in FisherPorter reactors $(0.1 \mathrm{~L}$ or $4 \mathrm{~L})$ equipped with mechanical stirrer. Under ethylene atmosphere, the proper amounts of solvent (toluene or hexane) and MAO were introduced sequentially. After complete thermal equilibration, the slurry solution containing $\mathbf{1}$ or $1 / \mathrm{C} 30 \mathrm{~B}$ was added with stirring. The total pressure was kept constant by a continuous feed of ethylene. The polymerization runs were stopped by introducing acidic ethanol. The polymers were washed with acidic ethanol, then ethanol and water, and dried in a vacuum oven at $60{ }^{\circ} \mathrm{C}$ for $12 \mathrm{~h}$.

\section{Intercalated Ti catalyst and PE-nanocomposite characterization}

An inductively coupled plasma optical emission (ICP-OES) spectrometer from PerkinElmer (Optima ${ }^{\mathrm{TM}}$ 2000 DV) was used for Ti measurement in the clay. A Scott spray chamber and a GemCone ${ }^{\circledR}$ nebulizer composed the sample introduction system. Catalyst digestion was done with $\mathrm{H}_{2} \mathrm{SO}_{4}$ and $\mathrm{HNO}_{3}\left(\mathrm{H}_{2} \mathrm{SO}_{4} / \mathrm{HNO}_{3}, 3: 1\right)$ in Teflon ${ }^{\circledR}$ capped vessel. The mixture was heated at $160{ }^{\circ} \mathrm{C}$ for $8 \mathrm{~h}$ in a heating block (Tecnal, Brazil). Sample and blank were analyzed in duplicate. The intrinsic viscosity of the neat PE and PE-MMT nanocomposite samples were analyzed using in a modified procedure in which the PE was firstly dissolved in decaline (concentrations of $0.02 \mathrm{~g} \mathrm{dL}^{-1}$ ) at $165{ }^{\circ} \mathrm{C}$, filtered through a $0.2 \mathrm{~mm}$ filter in order to remove the clay structure and then the PE solution was transferred quickly to a modified Ubelohde viscometer at $135{ }^{\circ} \mathrm{C}$. Based on the experimental intrinsic viscosity values [ $\eta$ ] it was possible to calculate the viscometric molar mass according to the formula $[\eta]=\mathrm{k}\left(\overline{\mathrm{M}}_{\mathrm{v}}\right)^{\alpha}$, for $\mathrm{k}=6.7 \times 10^{-4} \mathrm{dL} \mathrm{g}^{-1}$ and $\alpha=0.67 .{ }^{35}$ Thermal and crystallization behaviors were determined using Thermal Analysis 2100/TA Instruments. The temperature and energy readings were calibrated with indium and zinc according to ASTM D3417 and D3418. All measurements were carried out in nitrogen atmosphere. The sample was heated to $150{ }^{\circ} \mathrm{C}$, kept at this temperature for $5 \mathrm{~min}$, then cooled and heated at constant rates of $5{ }^{\circ} \mathrm{C} \mathrm{min}^{-1}$. Thermogravimetric (TG) was carried out under dried air with a Thermal 
Analysis Instruments Q500 Thermogravimetric Analyzer with a heating rate of $10{ }^{\circ} \mathrm{C} \mathrm{min}-1$ from room temperature to $900{ }^{\circ} \mathrm{C}$. The percentage of residual ashes (filler) was taken as the value reported at $600^{\circ} \mathrm{C}$. Dynamic Mechanical Thermal Analysis (DMTA) was carried out using a TA Instruments 2980 operating in the tensile mode. The sample dimensions were $0.15 \times 7.0 \times 12 \mathrm{~mm}$. Measurements were taken at $1 \mathrm{~Hz}$. The temperature was raised from -150 to $150^{\circ} \mathrm{C}$, at a scanning rate of $2^{\circ} \mathrm{C} \mathrm{min}^{-1}$. The flexural moduli of the nanocomposites were evaluated using a Universal Test Machine (INSTRON 4204) according to ASTM D-790. The tensile bars (at $23{ }^{\circ} \mathrm{C}$ ) of neat and PE-clay were submitted to a deformation force over two supports, the force was applied at the bar central point at selected displacement rate of $13 \mathrm{~mm} \mathrm{~min}^{-1}$, the sample dimensions were $13 \times 57 \times 19 \mathrm{~mm}$. Heat Deflection Temperature was measured using a CEAST Vicat Auto machine Model P/N 6970.000 according to ASTM D 648. The sample position was edgewise and surface stress was 0.45 or $1.82 \mathrm{MPa}$. Silicon oil was used to facilitate the heat transfer; the temperature was registered at $0.25 \mathrm{~mm}$ deflection. The X-ray diffractograms were obtained with a Siemens D-500 diffractometer. Films were scanned in the reflection mode using an incident $\mathrm{X}$-ray of $\mathrm{Cu} \mathrm{K}_{\alpha}$ radiation with wavelength of $1.542 \AA$ at a step size of $0.05^{\circ} \mathrm{min}^{-1}$ from $2 \theta=1^{\circ}$ to $10^{\circ}$. The transmission electronic microscopy analysis was carried out using ultra thin cuts obtained from the compressed specimens in a JEOL JEM-120 EXII TEM microscope operating at an accelerating voltage of $80 \mathrm{kV}$. The cuts were placed on 300 mesh $\mathrm{Cu}$ grids.

\section{Results and Discussion}

The organomodified Cloisite ${ }^{\circledR} 30 \mathrm{~B}$ (C30B) was selected considering the hydroxyl groups attached to the alkylammonium cations in the clay galleries which can act as the potential binding sites for coordination of the titanium complex. ${ }^{34}$ Thus, the predried $\mathrm{C} 30 \mathrm{~B}$ reacted with

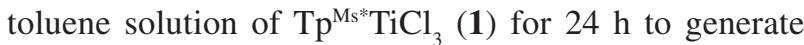
the intercalated titanium catalyst 1/C30B (Scheme 1). The resulting metal content on the clay determined by ICP-OES was $20 \mu \mathrm{mol} \mathrm{Ti}^{-1}$ of clay. On the basis of the powder $\mathrm{X}$-ray diffraction (XRD) analysis, it was observed that the basal spacing of the predried C30B changes from $1.85 \mathrm{~nm}$ $(2 \theta=4.8)$ to $2.18 \mathrm{~nm}(2 \theta=4.0)$ indicating that the intercalation of the titanium catalyst into the clay gallery took place (Figure 1). In this case, the increased spacing from predried $\mathrm{C} 30 \mathrm{~B}$ to $1 / \mathrm{C} 30 \mathrm{~B}$ is consistent with the

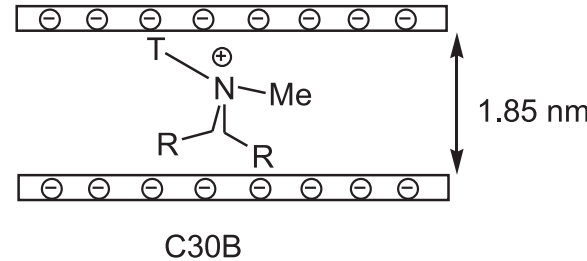

$\mathrm{R}=\mathrm{CH}_{2} \mathrm{CH}_{2} \mathrm{OH}$

$\mathrm{T}$ is Tallow $\left(\sim 65 \% \mathrm{C}_{18} ; \sim 30 \% \mathrm{C}_{16} ; \sim 5 \% \mathrm{C}_{14}\right)$

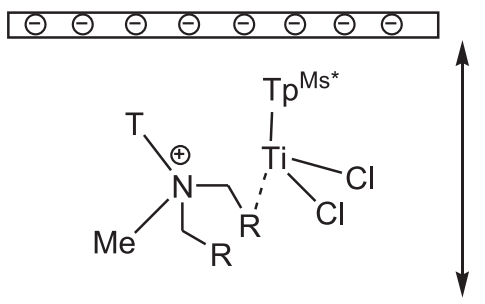

$2.18 \mathrm{~nm}$

$1 / \mathrm{C} 30 \mathrm{~B}$

Scheme 1

Table 1. Ethylene polymerization results using $\mathbf{1}$ and $1 / \mathrm{C}^{3} 0 \mathrm{~B}^{a}$

\begin{tabular}{lccccccccccc}
\hline Entry & $\mathrm{T} /{ }^{\circ} \mathrm{C}$ & {$[\mathrm{Al}] /[\mathrm{Ti}]$} & time $/ \mathrm{min}$ & $\mathrm{m}_{\text {clay }} / \mathrm{g}$ & $\mathrm{m}_{\text {pol/clay }} / \mathrm{g}$ & activity $^{\mathrm{b}}$ & $\mathrm{T}_{\mathrm{c}} /{ }^{\circ} \mathrm{C}$ & $\mathrm{T}_{\mathrm{m}} /{ }^{\circ} \mathrm{C}$ & $\begin{array}{c}\Delta \mathrm{H}_{\mathrm{m}} / \\
\left(\mathrm{mJ}^{-1}\right)\end{array}$ & $\chi /(\%)$ & $\mathrm{clay}^{\mathrm{c}} /(\%)$ \\
\hline $1^{\mathrm{d}}$ & 60 & 500 & 30 & - & 1.700 & 1739 & 119 & 136 & 200 & 70 & - \\
2 & 30 & 500 & 60 & 0.103 & 0.183 & 40 & 113 & 136 & 117 & 41 & 56 \\
3 & 60 & 500 & 60 & 0.100 & 0.700 & 300 & 116 & 136 & 166 & 58 & 14 \\
4 & 80 & 500 & 60 & 0.105 & 0.499 & 197 & 113 & 137 & 149 & 52 & 21 \\
$5^{\mathrm{d}, \mathrm{e}}$ & 60 & 2500 & 10 & - & 184.0 & 8762 & 119 & 135 & 177 & 62 & - \\
$6^{\mathrm{e}}$ & 60 & 2500 & 10 & 6.300 & 126.0 & 6000 & 121 & 135 & 189 & 66 & 5 \\
\hline
\end{tabular}

aPolymerization conditions: Fischer Porter bottle $(100 \mathrm{~mL})$, [Ti] $=2 \mu \mathrm{mol}$, toluene $=70 \mathrm{~mL} ; \mathrm{MAO}$ as cocatalyst, $\mathrm{P}_{\mathrm{C} 2 \mathrm{H} 4}=3.0 \mathrm{~atm} ;{ }^{\mathrm{b}} \mathrm{kg}$ of PE$/ \mathrm{mol}[\mathrm{Ti}] \mathrm{h}$; ${ }^{c}$ percentage determined by TGA; dethylene polymerization using $\mathbf{1}$ in homogeneous phase. ${ }^{\mathrm{e}}[\mathrm{Ti}]=126 \mu \mathrm{mol}$, hexane $=2 \mathrm{~L}$; MAO as cocatalyst, $\mathrm{P}_{\mathrm{C} 2 \mathrm{H} 4}=6.0 \mathrm{~atm}$. 
molecular dimensions of the titanium catalyst whereas the mesityl groups present in $\mathrm{Tp}^{\mathrm{Ms}^{*}}$ ligand determine significant steric crowding around the $\mathrm{TiCl}_{3}$ unit. ${ }^{34}$

The ethylene polymerization behavior of $1 / \mathrm{C} 30 \mathrm{~B}$ has been evaluated using methylaluminoxane (MAO) as cocatalyst. Representative results are given in Table 1. Initial study carried out at $60{ }^{\circ} \mathrm{C}$ with MAO-to-Ti ratio of 500 showed that this catalytic system was possible to polymerize ethylene with activity of $300 \mathrm{~kg}$ of PE per (mol [Ti] h) (entry 3). As expected, the intercalated catalyst showed lower activity than the one presented by the equivalent homogeneous system (entry $1,1739 \mathrm{~kg}$ of PE per (mol [Ti] h)) in consequence of lower amount of potentially available Ti centers present into the clay gallery. However, lower ethylene diffusion into the gallery, which would induce catalyst decay, cannot be ruled out.

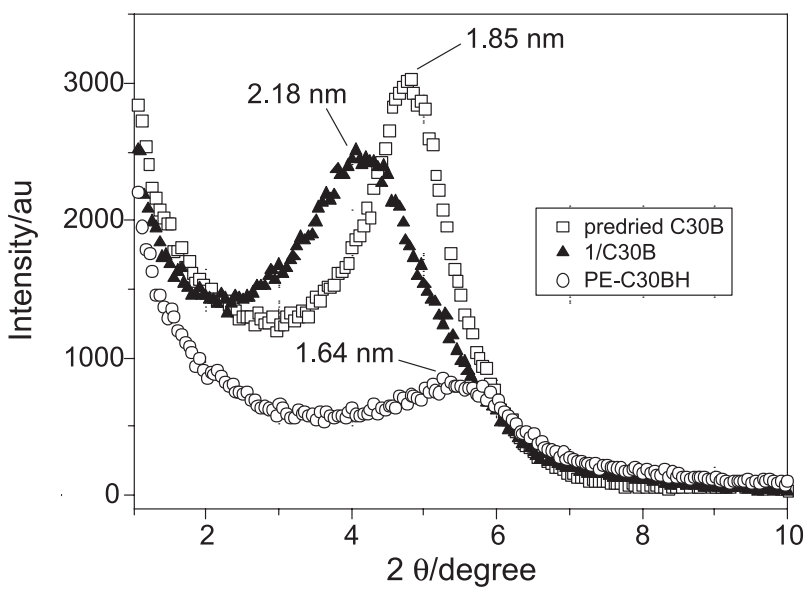

Figure 1. X-ray diffractograms of the activated C30B, 1/C30B and PEC30BH nanocomposite.

The influence of polymerization temperature on activity has been evaluated in the range of $30-80{ }^{\circ} \mathrm{C}$ with $\mathrm{MAO}$-to-Ti ratio of 500 . The optimal operating temperature for $1 / \mathrm{C} 30 \mathrm{~B}$ is $60^{\circ} \mathrm{C}$. At $30^{\circ} \mathrm{C}$, a very low activity was found for this catalytic system, while at $80{ }^{\circ} \mathrm{C}$ partial catalyst deactivation was observed.

The melting point $\left(\mathrm{T}_{\mathrm{m}}\right)$ of the PE-MMT nanocomposites (PE-C30B) was not affected by the presence of clay $\left(136-137{ }^{\circ} \mathrm{C}\right)$. On the other hand, lower crystallization temperatures $\left(T_{c}\right)$ have been found for these polymeric materials in comparison with the neat PE. In addition, for all filled polymers a loss of crystallinity can be detected which is observable in the reduction of $\Delta \mathrm{H}_{\mathrm{m}}$ (entry 1, vs 2-4). It can be supposed that this behavior is due to the presence of higher amounts of clay in the PE matrix (14-56 wt.\%) that difficults the crystallization process.

Based on these results, some additional reactions were performed in order to decrease the amount of clay in the polymeric matrix. For that, the ethylene polymerization reactions were carried out in a 4L Fischer Porter reactor using hexane as solvent at higher ethylene pressure (6 atm) ${ }^{36,37}$ Under these polymerization conditions, the activity for 1 reached $8762 \mathrm{~kg}$ of PE per mol [Ti] h while the use of $1 / \mathrm{C} 30 \mathrm{~B}$ displayed an activity of $6000 \mathrm{~kg}$ of PE per (mol [Ti] h) (entries 5-6). In this case, the lower amount of clay (5 wt.\%) incorporated in the PE matrix (PE-C30BH) determined a small impact on the $\mathrm{T}_{\mathrm{m}}\left(135^{\circ} \mathrm{C}\right)$ and $\mathrm{T}_{\mathrm{c}}\left(121{ }^{\circ} \mathrm{C}\right)$ attaining values very close to those ones of the neat PE. Moreover, for PE-C30BH nanocomposite was observed a slightly increase of crystallinity $\left(\Delta \mathrm{H}_{\mathrm{m}}=189 \mathrm{~mJ} \mathrm{mg}^{-1}\right)$ compared to neat $\mathrm{PE}\left(\Delta \mathrm{H}_{\mathrm{m}}=177 \mathrm{~mJ} \mathrm{mg}^{-1}\right)$ which can be associated to the nucleation effect of the MMT on the PE.

The viscosity-average molecular weight $\left(\overline{\mathrm{M}}_{\mathrm{v}}\right)$ values indicated the formation of ultra high molecular weight PE (UHMWPE); however the presence of clay particles provided a production of $\mathrm{PE}$ with lower molecular weight $\left(2.94 \times 10^{6} \mathrm{~g} \mathrm{~mol}^{-1}\right)$ in comparison with the neat PE $\left(4.85 \times 10^{6} \mathrm{~g} \mathrm{~mol}^{-1}\right)$. Such results suggest that the presence of well-dispersed clay in the PE matrix can retard the diffusion of ethylene and consequently the probability of chain propagation decreases with the clay loading. ${ }^{38,39}$

The montmorillonite exfoliation/dispersion within the PE matrix has been analyzed by both XRD and transmission electronic microscopy (TEM). The powder XRD of the PE-C30BH showed the absence of the diffraction peak at $2 \theta=4.8$ indicating the formation of an exfoliated PE-MMT nanocomposite (Figure 1). In addition, the appearance of weak intensity diffraction peak at $2 \theta=5.4$ suggests the occurrence of non exfoliated clay with lower basal spacing $(1.64 \mathrm{~nm})$ that can be associated with the presence of natural no modified montmorillonite (MMT-Na).

Transmission electron micrographs of microtomed section of PE-C30BH nanocomposite confirmed homogeneous distribution of clay into the PE matrix as presented in Figure 2. Uniform dispersion is important because if the matrix consists of aggregates of particles, the stress field in the vicinity of the aggregate will be high, resulting in easier crack initiation and propagation, and consequent premature failure. In addition, Figure 2 reveals a good exfoliation of the $\mathrm{C} 30 \mathrm{~B}$, with some few multilayer tactoids with expanded layer spacing still remaining.

Overall, their mechanical properties showed some improvements when compared with those ones displayed by the PE produced using exclusively $\mathbf{1}$. For instance, for the PE-C30BH it was observed an increase of the flexural modulus from 1050 (neat PE) to $1300 \mathrm{MPa}$, which is an improvement of $24 \%$. Moreover, it was observed an increase of $10 \%$ in the temperature of deflection (HDT, 


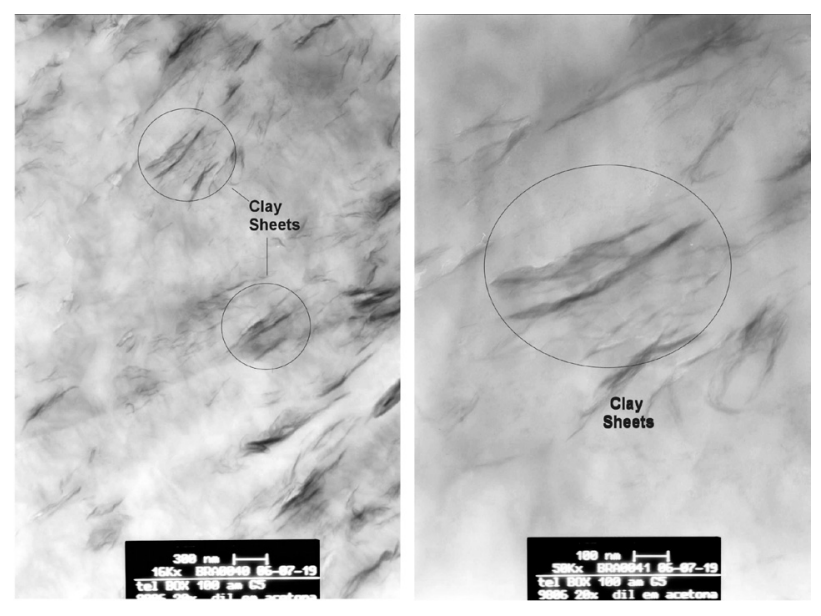

Figure 2. TEM images for a PE-C30BH nanocomposite containing $5 \mathrm{wt} . \%$ of organo-modified montmorillonite (entry 6).

from 43 to $48{ }^{\circ} \mathrm{C}$ ). From DMA results it can be found that the incorporation of $\mathrm{C} 30 \mathrm{~B}$ increases significantly the storage modulus $\left(\mathrm{E}^{\prime}\right)$ of $\mathrm{PE}$ over the entire temperature range investigated which can be associated to the stiffening effect of the clay. In this case, the presence of C30B in the PE matrix increased storage modulus from $219.9 \mathrm{MPa}$ (neat $\mathrm{PE})$ to $853.9 \mathrm{Mpa}$ as can be seen in Figure 3.

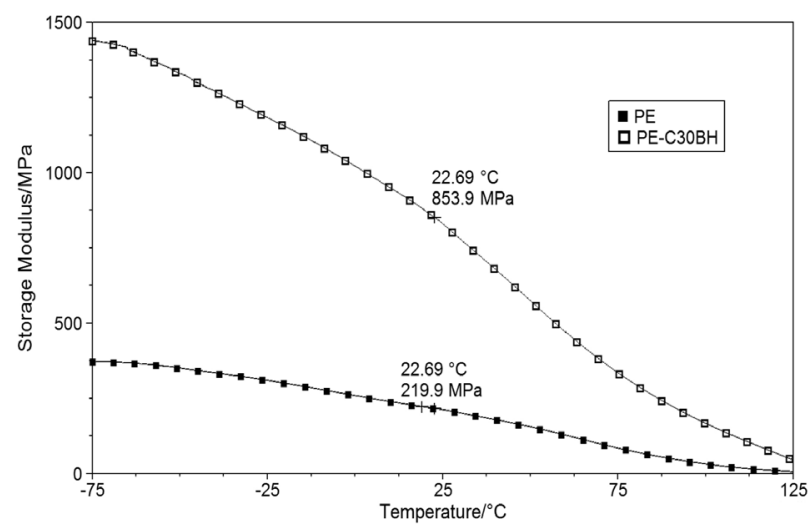

Figure 3. Storage modulus E’ for neat $\mathrm{PE}$ and $\mathrm{PE}-\mathrm{C} 30 \mathrm{BH}$ nanocomposite.

\section{Conclusions}

We have successfully intercalated $\mathbf{1}$ into the clay gallery and the resulting catalyst system was able to polymerize ethylene towards the production of PE-MMT nanocomposites. Both XRD and TEM results confirmed the uniform distribution of silicate layers of MMT in the whole PE matrix and the production of exfoliated PE-MMT nanocomposites. Some mechanical properties such as flexural modulus and storage modulus of PE-MMT nanocomposites showed some improvements when compared with those ones displayed by the neat PE produced using exclusively $\mathbf{1}$.

\section{Acknowledgments}

This work was supported by Braskem S.A and CTPETRO/ CNPq (proc. 550145/05-2). Mariana S. Beauvalet, Fernando Junges and Adriana C. A. Casagrande gratefully acknowledge CNPq for the fellowships. The authors thank Braskem S.A for the permission to publish this work.

\section{Reference}

1. Komori, Y.; Kuroda, K.; Polymer-Clay Nanocomposites, Pinnavaia, T. J.; Beall, G. W., eds.,: John Wiley and Sons Ltd.: New York, 2001, pp. 3-18.

2. Harrats, C.; Groeninckx, G.; Macromol. Rapid Commun. 2008, $29,14$.

3. Gorrasi, G.; Tortora, M.; Vittoria, V.; Kaempfer, D.; Mülhaupt, R. Polymer 2003, 44, 3679.

4. Okada, A.; Usuki, A.; Macromol. Mater. Eng. 2006, 291, 1449.

5. Alexandre, M.; Dubois, Ph.; Mater. Sci. Eng., R 2000, $28,1$.

6. Mariott, W. R.; Chen, E. Y-X.; J. Am. Chem. Soc. 2003, 125, 15726.

7. Zeng, C.; Lee, L. J.; Macromolecules 2001, 34, 4098.

8. Huskic, M.; Zigon, M.; Eur. Polym. J. 2007, 43, 4891.

9. Paul, M. A.; Alexandre, M.; Degée, P.; Calberg, C.; Jérôme, R.; Dubois, P.; Macromol. Rapid Commun. 2003, 24, 561.

10. Rehab, A.; Akelah, A.; Agag, T.; Shalaby, N.; Polym. Adv. Technol. 2007, 6, 463.

11. Lepoittevin, B.; Pantoustier, N.; Devalckenaere, M.; Alexandre, M.; Kubies, D.; Calberg, C.; Macromolecules 2002, 35, 8385.

12. Liao, L.; Zhang, C.; Gong, S.; Macromol. Rapid Commun. 2007, $28,1148$.

13. Zeng, Q.H.; Wang, D.Z.; Yu, A.B.; Lu, G.Q.; Nanotechnology 2002, 13, 549.

14. Akelah, A.; Rehab, A.; Agag, T.; Betiha, M.; J. Appl. Polym. Sci. 2006, 103, 3739.

15. Essawy, H. A.; Badran, A. S.; Youssef, A. M.; El-Hakim, A. E-F. A. A.; Macromol. Chem. Phys. 2004, 205, 2366.

16. Du, K.; He, A. H.; Liu, X.; Han, C. C.; Macromol. Rapid Commun. 2007, 28, 2294.

17. He, A.; Wang, L.; Li, J.; Dong, J.; Han, C. C.; Polymer 2006, 47, 1767.

18. He, A. H.; Hu, H. Q.; Huang, Y. J.; Dong, J. Y.; Han, C. C.; Macromol. Rapid Commun. 2004, 25, 2008.

19. Sun, T.; Garcés, J. M.; Adv. Mater. 2002, 14, 128.

20. Tudor, J.; Willington, L.; O'Hare, D.; Chem. Commun. 1996, 2031.

21. Jongsomjit, B.; Panpranot, J.; Praserthdam, P.; Mater. Lett. 2007, $61,1376$.

22. Qian, J.; Guo, C-Y.; Wang, H.; Hu, Y.; J. Mater. Sci. 2007, 42, 4350. 
23. Malucelli, G.; Ronchetti, S.; Lak, N.; Priola, A.; Dintcheva, N. T.; La Mantia, F. P.; Eur. Polym J. 2007, 43, 328.

24. Bergman, J. S.; Chen, H.; Giannelis, E. P.; Tomas, M. G.; Coates, G. W.; Chem. Commun. 1999, 2179.

25. Heinemann, J.; Reichert, P.; Thomann, R.; Mülhaupt, R.; Macromol. Rapid Commun. 1999, 20, 423.

26. He, F-A.; Zhang, L-M.; Jiang, H-L.; Chen, L-S.; Wu, Q.; Wang, H-H.; Compos. Sci. Technol. 2007, 67, 1727.

27. He, F-A.; Zhang, L-M.; Nanotechnology 2006, 17, 5941.

28. Huang, Y.; Yang, K.; Dong, J-Y.; Macromol. Rapid Commun. 2006, 27, 1278.

29. Huang, Y.; Yang, K.; Dong, J-Y.; Polymer 2007, 48, 4005.

30. Jin, Y-H.; Park, H-J.; Im, S-S.; Kwak, S-Y.; Kwak, S.; Macromol. Rapid Commun. 2002, 23, 135.

31. Xu, J-T.; Zhao, Y-Q.; Wang, Q.; Fan, Z-Q.; Polymer 2005, 46, 11978.

32. Kuo, S-W.; Huang, W-J.; Huanga, S-B.; Kaoa, H-C.; Chang, F-C.; Polymer 2003, 44, 7709.
33. Alexandre, M.; Dubois, Ph.; Sun, T.; Garces, J. M.; Jérôme, R.; Polymer 2002, 43, 2123.

34. Murtuza, S.; Casagrande, O. L. Jr.; Jordan, R. F.; Organometallics 2002, 21, 1882.

35. Chiang, R.; J. Polym. Sci. 1959, 36, 91.

36. Casagrande, O. L. Jr.; Casagrande, A. C. A.; Junges, F.; Beuavalet, M. S.; Barbosa, C. A. S.; Mauler, R. S.; Mota, F. F.; Oviedo, M. A. S.; Br Patent 0602894-2, 2006.

37. Casagrande, O. L. Jr.; Casagrande, A. C. A.; Junges, F.; Beuavalet, Mauler, R. S.; Mota, F. F.; Br Patent 0605664-4, 2006.

38. Fu, X.; Qutubuddin, S.; Polymer 2001, 42, 807.

39. Zhong, Y.; Zhu, Z.; Wang, S-Q.; Polymer 2005, 46, 3006.

Received: September 14, 2008 Web Release Date: February 13, 2009 